\title{
DUElprloniel Td
}

DOE/PC/90051--T8

Report No. PETC 34-92

DE93 008041

ANAEROBIC BIOPROCESSING OF LOW-RANK COALS

CONTRACT No. DE-AE22-90PC90051

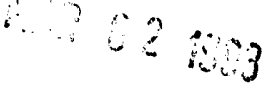

$-3 i$

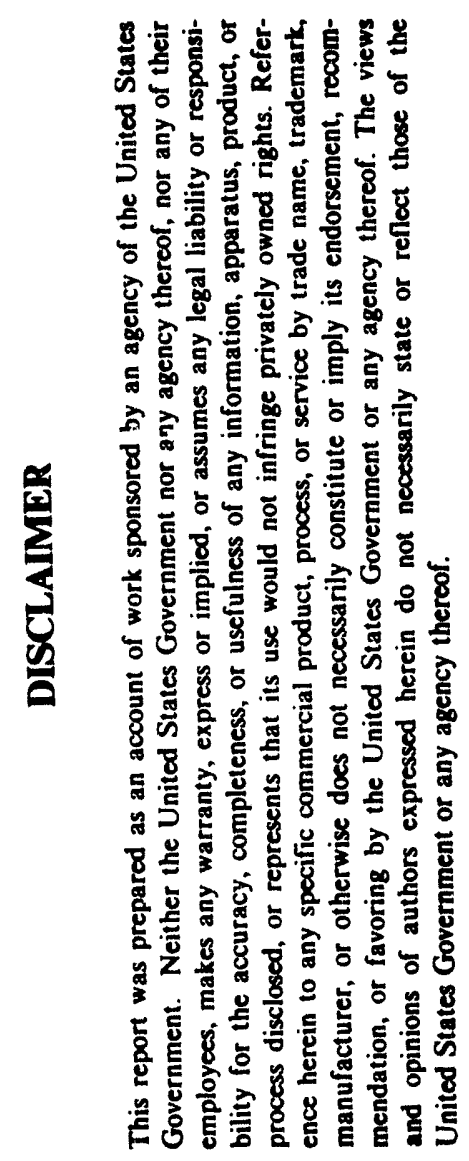

PROGRESS REPORT

July 1 - September 30, 1992

Mahendra K. Jain

Ramani Narayan

Ohantaek Han

Michigan Biotechnology Institute

3900 Collins Road

P.O. Box 27609

Lansing, Michigan 48909 


\section{QUARTERLY PROGRESS REPORT}

Anaerobic Processing of Low-Rank Coals

Contract No. DE-AC22-90PC90051

July 1 - September 30,1992

\section{INTRODUCTION}

The overall goal of this project is to find biological methods to remove carboxylic functionalities from low-rank coals and to assess the properties of the modified coal towards coal liquefaction. The main objectives for this quarter were: (i) continuation of microbial consortia maintenance and completion of coal decarboxylation using batch reactor system, (ii) decarboxylation of model polymer, (iii) characterization of biotreated coals, and (iv) microautoclave liquefaction of the botreated coal.

\section{QUARTERLY PROGRESS SUMMARY}

- Thermogravimetric analysis of coal biotreated in the absence of methanogens and under $5 \%$ hydrogen gas exhibits increased volatile carbon to fixed carbon (VC/FC) ratio.

- Microbial consortia developed on coal are being adapted to two different model polymers containing free carboxylic groups to examine decarboxylation ability of consortium.

- Experiments to decarboxylate two model polymers, poly (acrylic acid) and poly (methyl methacrylate), have been completed and the data are being analyzed.

- Biotreated coal showed increase in THF-solubles.

- Biotreated coal samples were sent to DOE-PETC for 'iquefaction studies.

\section{PROGRESS REPORT}

Coal decarboxylation under the batch fermentor systems: Three batch systems were completed on day 51. The biotreated $c$ 'als were filtered and freeze-dried. The freeze-dried coals and control coal were analyzed usiıg DuPont thermogravimetric analyzer. The results (Table 1) indicate that $\mathrm{VC} / \mathrm{FC}$ ratio of biotreated coal under non-methanogenic conditions increased by $6.3 \%$. 
Table 1. Thermogravimetric analysis of biotreated coals in the fermentor system

\begin{tabular}{|c|c|c|c|c|c|c|}
\hline & Gas phase & $\begin{array}{c}\text { Inhibition } \\
\text { of } \\
\text { methanogens }\end{array}$ & $\begin{array}{c}\text { Volatile } \\
\text { Carton } \\
\text { (VC) }\end{array}$ & $\begin{array}{c}\text { \% Fixed } \\
\text { Carton } \\
\text { (FC) }\end{array}$ & $\begin{array}{c}\% \\
\text { VC/FC } \\
\text { ratio }\end{array}$ & $\begin{array}{c}\text { Increase } \\
\text { in VC/FC } \\
\text { ratio }\end{array}$ \\
\hline Control Coal & - & - & 45.69 & 46.52 & 0.982 & - \\
\hline$\# 16$ & Nitrogen & No & 43.55 & 43.71 & 0.994 & 1.46 \\
\hline$\# 17$ & Nitrogen & Yes & 44.10 & 42.26 & 1.044 & 6.27 \\
\hline$\# 18$ & $\begin{array}{c}5 \% \text { Hydrogen } \\
+95 \% \\
\text { Nitrogen }\end{array}$ & No & 42.40 & 43.50 & 0.975 & -0.75 \\
\hline
\end{tabular}

Thermogravimetric analysis of biotreated coal: Wyodak subbituminous coal was decarboxylated under $5 \% \mathrm{H}_{2}+95 \% \mathrm{~N}_{2}$ and $100 \% \mathrm{~N}_{2}$ gas phase in anaerobic tubes. The experiment was conducted to reconfirm changes in VC/FC ratio observed earlier. Biotreated coals were centrifuged and freeze-dried for TGA analysis. The results showed about $5 \%$ increase in VC/FC ratio of coal treated under $5 \% \mathrm{H}_{2}$ over control (Table 2 ).

Table 2. Thermogravimetric analysis of biotreated coals in anaerobic tubes

\begin{tabular}{|c|c|c|c|c|c|}
\hline Coal Sample & $\begin{array}{c}\text { \% Volatile } \\
\text { Carbon (VC) }\end{array}$ & $\begin{array}{c}\text { \% Fixed } \\
\text { Carbon (FC) }\end{array}$ & \% Ash & VC/FC ratio & $\begin{array}{c}\text { \% Increase } \\
\text { in VC/FC } \\
\text { ratio }\end{array}$ \\
\hline Control & 44.79 & 45.80 & 9.41 & 0.9779 & - \\
\hline $5 \%$ Hydrogen & 45.10 & 44.06 & 10.84 & 1.0237 & 4.68 \\
\hline $100 \%$ Nitrogin & 44.25 & 44.82 & 10.93 & 0.9874 & 0.97 \\
\hline
\end{tabular}

Coal decarboxylation in anaerobic vials: Coal samples decarboxylated by various microbial consortia in anaerobic vials were also determined for VC/FC ratio (Table 3). The results indicate that consortium RW8 was more effective than the consortium LCC5. These results are in good agreement with GC data of carbon dioxide and methane in the headspace of the vials. 
Table 3. TGA results of biotreated coals by various consortia in anaerobic vials

\begin{tabular}{|c|c|c|c|c|c|}
\hline Coal Sample & $\begin{array}{c}\text { Consortium } \\
\text { used }\end{array}$ & $\begin{array}{c}\text { \% Volatile } \\
\text { Carbon (VC) }\end{array}$ & $\begin{array}{c}\text { \% Fixed } \\
\text { Carbon (FC) }\end{array}$ & VC/FC ratio & $\begin{array}{c}\text { \% Increase } \\
\text { in VC/FC } \\
\text { ratio }\end{array}$ \\
\hline Control & - & 44.81 & 46.33 & 0.9672 & - \\
\hline A & RW8 & 44.96 & 45.18 & 0.9951 & 2.88 \\
\hline B & LCC5 & 43.75 & 45.71 & 0.9570 & -1.05 \\
\hline
\end{tabular}

Model Polymers: Decarboxylation using the partially hydrolyzed poly (methyl methacrylate), PMMA, and polyacrylic acid were completed on day 35. PMMA and its derivatives were added @ 2\% in anaerobic tubes with consortium RW11. All samples were prepared as duplicate. Gas production from polymer with sodium succinate decreased in the presence of either polymer. Surprisingly, gas production from the partially hydrolyzed PMMA was greatly increased by adding $0.4 \%$ of sodium succinate. However, in the presence of $0.5-5 \%$ polyacrylic acid, gas production was severely decreased under all experimental conditions, indicating severe inhibition of methanogenic bacteria and probably decarboxylating organisms by polyacrylic acid.

Coal characterization and liquefaction: Five coal samples consisting a control coal sample, two decarboxylated demineralized coals and two decarboxylated normal coals have been sent to $\mathrm{Dr}$ Serio (Advanced Fuel Research, CT) for pyrolysis FT-IR analysis. Two coal samples (control coal and biotreated coal) were sent to Dr. Warzinski (DOE-PETC) to conduct liquefaction studies with these coal samples.

Solvent solubilities of biotreated coal: The effect of biotreatment on coal was measured by the amount of coal product solubilized in organic solvents per unit of time as reported in earlier work (Narayan 1987; Narayan et al., 1987; Huang and Narayan, 1987). The THF and toluene were used for extracting soluble coal product using the Soxhlet extraction apparatus overnight. The solvent extract was concentrated and finally dried under vacuum at $75^{\circ} \mathrm{C}$ for $\mathrm{THF}$ and $85^{\circ} \mathrm{C}$ for toluene. Generally, THF-soluble coal products were greatly increased by anaerobic biotreatment, while toluene-solubles were not changed to a great extent as seen in Tables 4 and 5, respectively. The highest increase in THF solubles was observed in \#13 batch system where the consortium LC-4C3 was inoculated in coal medium containing $1.6 \mathrm{~g}$ of sodium succinate and $0.8 \mathrm{~g}$ of ammonium chloride. Increases in toluene-solubles were observed in only two batch systems of $\# 7$ and \#13. These results indicate that anaerobic biotreatment can change the property of coal in terms of solvent solubility which would provide a better feedstock toward coal liquefaction. 
Table 4. THF solubility of biotreated coal from batch fermentor system

\begin{tabular}{|c|c|c|}
\hline Batch No. & THF-solubles (\%) & Increase over control (\%) \\
\hline Control & 3.77 & - \\
\hline$\# 3$ & 4.84 & 28.4 \\
\hline$\# 4$ & 5.43 & 44.1 \\
\hline$\# 5$ & 5.57 & 47.7 \\
\hline$\# 6$ & 4.10 & 8.7 \\
\hline$\# 7$ & 5.92 & 56.9 \\
\hline$\# 8$ & 5.82 & 54.3 \\
\hline$\# 10$ & 5.08 & 34.9 \\
\hline$\# 11$ & 5.30 & 40.5 \\
\hline$\# 13$ & 6.44 & 70.9 \\
\hline$\# 17$ & 4.30 & 14.0 \\
\hline$\# 18$ & 5.24 & 38.9 \\
\hline
\end{tabular}

Table 5. Toluene solubility of biotreated coal from batch fermentor system

\begin{tabular}{|c|c|c|}
\hline Batch No. & Toluene-Solubles (\%) & Increase over control (\%) \\
\hline Control & 1.75 & - \\
\hline$\# 3$ & 1.61 & -7.8 \\
\hline$\# 4$ & 1.47 & -15.9 \\
\hline$\# 5$ & 1.52 & -12.9 \\
\hline$\# 6$ & 1.41 & -19.3 \\
\hline$\# 7$ & 1.78 & +2.0 \\
\hline$\# 8$ & 1.59 & -9.2 \\
\hline$\# 10$ & 1.58 & -9.9 \\
\hline$\# 11$ & 1.15 & -34.3 \\
\hline$\# 13$ & 1.98 & +12.9 \\
\hline$\# 17$ & 1.54 & -12.2 \\
\hline$\# 18$ & 1.33 & -24.0 \\
\hline
\end{tabular}




\section{SIGNIFICANT ACHIEVEMENTS}

1. Biotreated coal showed increased THF-solubles indicating it to be a better feed stock for liquefaction.

2. Increase in VC/FC ratio in the biotreated coal was reconfirmed.

\section{OBJECTIVES FOR NEXT QUARTER}

1. Complete characterization of biotreated coal.

2. Complete liquefaction of biotreated coal.

3. Complete analysis of biotreated demineralized vs. control coal.

4. Write reports. 

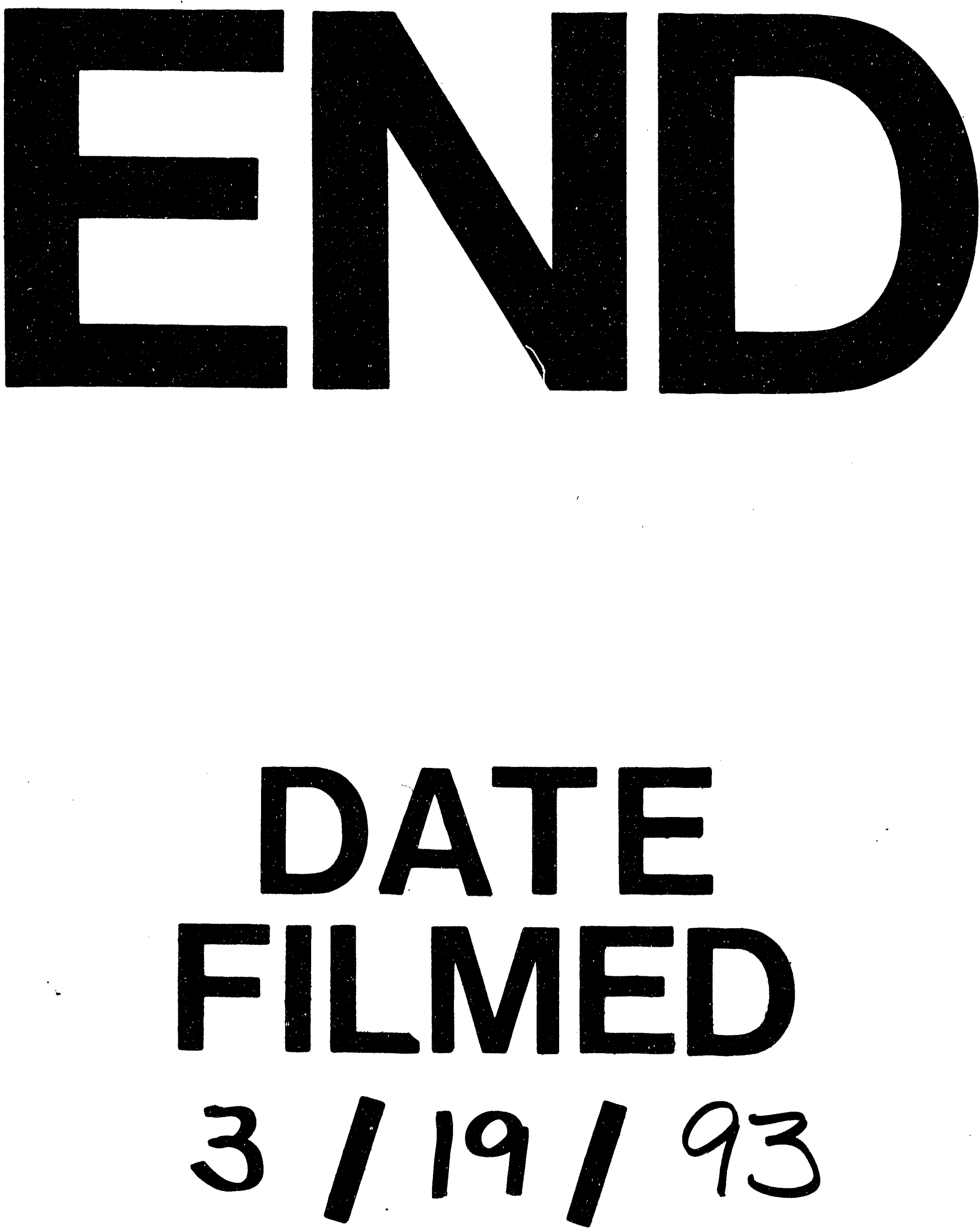
